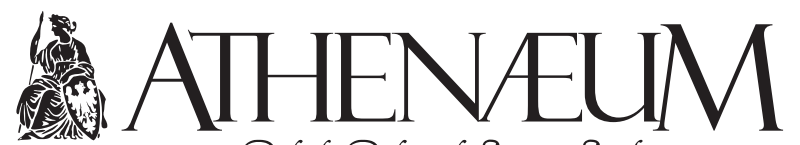

Polish Political Science Studies

Polskie Studia Politologiczne

vol. 64(4)/2019, pp. 216-231

DOI: 10.15804/athena.2019.64.13

www.athenaeum.umk.pl

ISSN 1505-2192

\title{
DIPLOMATIC SUBJECTIVITY OF FIFA IN THE CONTEXT OF SELECTING WORLD CUP HOST*
}

\author{
DYPLOMATYCZNA PODMIOTOWOŚĆ FIFA W KONTEKŚCIE \\ WYBIERANIA GOSPODARZA MISTRZOSTW ŚWIATA \\ W PIŁCE NOŻNEJ
}

Michał Marcin Kobierecki**

\begin{abstract}
The goal of the research was to investigate FIFA, one of the most important international sports organisations, from the perspective of its diplomatic subjectivity. It is a case study concerning the process of selection of the World Cup hosts by FIFA, in reference to the engagement of presidents, prime ministers and other representatives of national authorities of states that hosted FIFA World Cup in bidding for the tournament within last the 30 years. The hypothesis that was verified within the research assumed that through selecting World Cup host FIFA obtains diplomatic subjectivity. This refers to research questions concerning the willingness of state leaders to engage in contacts and negotiations with sports officials and reasons for such engagement.
\end{abstract}

Keywords: sports diplomacy; sport and politics; FIFA; public diplomacy; diplomacy

\section{ABSTRAKT}

Celem pracy jest zbadanie jednej z najważniejszych organizacji sportowych, jaką jest FIFA, z perspektywy jej dyplomatycznej podmiotowości. Badanie stanowi studium przypadku poświęcone procesowi wybierania gospodarzy mistrzostw świata w piłce nożnej w kontekście wspierania poszczególnych kandydatur przez prezydentów, premierów i innych przedstawicieli władz państw, którym ostatecznie przyznano organizację mistrzostw świata w ostatnich 30 latach. Hipoteza, która została poddana weryfikacji, zakładała, że poprzez wybieranie gospodarzy mistrzostw świata w piłce nożnej FIFA uzyskuje podmiotowość dyplomatyczną. Wiąże się to z pytaniami badawczymi dotyczącymi gotowości przywódców państwowych do angażowania się w kontakty i negocjacje $\mathrm{z}$ działaczami sportowymi oraz przyczyn takiego zaangażowania.

Słowa kluczowe: dyplomacja sportowa; sport i polityka; FIFA; dyplomacja publiczna; dyplomacja

* This work was supported by the National Science Centre, Poland [grant number 2015/19/D/ HS5/00513].

** University of Łódź, Faculty of International and Political Studies. 
Contemporary diplomacy is characterised by its diffusion. States are no longer the only diplomatic actors, since a growing role of non-state subjects such as sub-national and regional authorities, international organisations, multinational corporations, celebrities and non-governmental organisations can be observed (Adler-Nissen, 2016). International sports organisations are formally international non-governmental organisations that are not bound with any territory. This type of subjects, together with transnational corporations, are, according to Beata Surmacz (2015), key non-state diplomatic subjects. The goal of the research presented in the article is to investigate the Fédération Internationale de Football Association (FIFA), one of the most important international sports organisations, from the perspective of its diplomatic subjectivity understood as a capability of becoming the subject of diplomacy, which on the other hand, in case of such actors as international sports organisations, can be assessed on the basis of states' (the primary diplomatic subjects) willingness to engage in diplomatic contacts with them. The purpose of the paper is therefore to analyse if and how representatives of states such as presidents or prime ministers engaged in contacts with FIFA in connection with the selection of the FIFA World Cup host.

The research concerns one of the factors of diplomatic subjectivity of international sports federations (IFs), which is the right to select the hosts of sports events. Others include, for example, decisions to affiliate or not national sports federations, negotiating with other international actors including states, capability of exerting pressure on governments and other states' authorities, etc. When selection of hosts of sports events is considered, the FIFA World Cup belongs to sports mega-events, which can be described as a short lasting events but with social dimension going beyond the time of their occurrence, which offer entertainment for a mass audience (Palmer, 2013). By the example of state leader's engagement in bidding for the World Cup, the research aims to investigate FIFA's diplomatic significance. This refers to research questions concerning the willingness of state leaders to engage in contacts and negotiations with sports officials and reasons for such engagement. The hypothesis to be verified assumes that through selecting the World Cup host FIFA obtains diplomatic subjectivity.

The research refers to modernist approach of the study of international relations, particularly to institutional liberalism and interdependence liberalism. This approach is connected to broadening the field of research and taking into consideration not only states, but other subjects as well. The theoretical concept of multistakeholder diplomacy, represented, for example, by Brian Hocking, was 
particularly important for the research. It assumes the complexity of processes connected with pursuing politics, the need for wider cooperation and the engagement of many new actors in diplomatic processes (Beacom, 2012).

The research presented in the article is the case study concerning the process of selection of the World Cup hosts by FIFA, in reference to the engagement of presidents, prime ministers and other representatives of national authorities of the states that hosted the FIFA World Cup in bidding for the tournament in recent years. The research relates to the World Cups that were held since 1994 and will be held in the future but their hosts have been selected already, so the timeframe of the research encompass the period between 1988 (the decision on the 1994 World Cup) and 2018 (decision on the 2026 World Cup). Such timescale allowed to include up to date events and at the same time to make observations concerning numerous bidding processes within previous 30 years. The research referred to winning bids only, as these cases of state authorities' engagements could be retrieved from available sources.

Investigation included observation of the engagement of key state figures in the process of bidding for the event. This included participation or giving a speech during the ceremony of selecting the World Cup hosts, belonging to bidding committees, as well as other forms of lobbying by state leaders such as meeting with FIFA officials or posting on the Internet. The data have been acquired from secondary sources mostly, such as articles in the media or scientific articles or chapters. However, certain primary sources have also been used, such as the FIFA documents.

The presented methodology has been based on the assumption that diplomacy of the non-state actors such as international sports organisations is the spin-off result of the state's public diplomacy. States within their public diplomacy and nation-branding endeavours seek arenas for presenting themselves to the external publics in a desirable way. A sports mega-event such as the FIFA World Cup can be therefore perceived as a good way of promoting a state. IFs are, on the other hand, in possession of those events, which for instance means they have the right to select their hosts. This relation makes IFs the external stakeholders of state's public diplomacy. As a consequence, states within their desire to host sports mega-events become petitioners of the sports organisations and look for their support, thus engaging in contacts and negotiations with IFs, i.e., FIFA, in case of this particular research.

The article refers to the category of sports diplomacy, which is understood differently by various authors. For instance, it can be perceived as a whole range 
of international contacts between people connected with sport and politicians, that are motivated by foreign policy concerns and have implications for general relations between states (Merkel, 2016). However, apart from understanding it as a form of state's activity, it can also be perceived as the diplomacy that international sports governing bodies are engaged in. Stuart Murray and Geoffrey Pigman (2014) distinguished a category of international sport as diplomacy, by which they meant diplomatic representation, communication and negotiation between non-state actors that take place as a result of ongoing international sporting competition. According to this approach, international non-state sports actors such as the International Olympic Committee or FIFA practice a distinct type of diplomacy which includes undertaking negotiations with governments, local and regional sports organisations, sponsors, media firms and organisations of global civil society. This article obviously refers to this form of sports diplomacy, since an international sports organisation is the main subject of research. Still, its diplomatic subjectivity will be observed in reference to its contacts with states' political authorities.

The state of the art concerning the diplomacy of international sports governing bodies is being developed lately and several valuable research have been published. Most of them, however, refer to the International Olympic Committee. One of the most important works on the issue is Aaron Beacom's book International Diplomacy and the Olympic Movement: The New Mediators, in which he employed multistakeholder diplomacy model to analyse the Olympic Games as a diplomatic event on their own right. Other papers worth mentioning are articles by Verity Postlethwaite and Jonathan Grix (2016), or by Steve Jackson and Marcelle Dawson (2017). Among the studies dedicated to FIFA as a diplomatic actor, papers by Christiane Eisenberg (2005), or Heidrun Homburg (2006) should be mentioned. These and similar investigations, although valuable, are not very numerous and there still remains a number of gaps in the state of the art. The available research concerning the diplomacy of FIFA tends to focus on its role concerning state's attempts to use membership in IFs to foster international and national legitimisation. As for the selection of the World Cup hosts, authors tend to focus on bribery scandals and lack of transparency. Presented research aims to fill one of the gaps and to analyse the diplomacy of FIFA from an explicitly political science perspective. 


\section{THE PROCEDURE OF SELECTING WORLD CUP HOST}

Before moving to the main analysis, in order to fully understand the FIFA diplomacy concerning selection of the World Cup hosts, it is important to review the selection procedure. The FIFA World Cup is a sports mega-event under the ultimate control of FIFA. The decision on the venue is made by FIFA - the supreme authority of FIFA comprised of member associations, each having one vote. Another FIFA body engaged in the bidding process is the Council, consisting of the FIFA President, 8 vice-presidents, and 28 other members. The Council issues specific regulations for establishment of the bidding procedure, reviews the bids and submits up to three of them to Congress for the final decision (FIFA, 2018). In theory, the process is ultimately democratic, although it has been changed lately, partly in response to numerous bribery scandals within FIFA.

Previously the decision on the World Cup host was made by the Executive Committee (EC) - 24-member predecessor of the FIFA Council. The procedure was changed after the controversial selection of Russia and Qatar as the World Cup hosts in 2018 and 2022 respectively (Becker, 2013). The goal of the article is to assess how FIFA played a role of a diplomatic actor through selecting the hosts of the World Cup, it will mostly relate to the previous bidding rules. However, since the Council remains active within the selection process, the situation will probably remain similar in the context of FIFA's diplomacy. The changes FIFA underwent were supposed to tackle bribery, not the diplomatic capabilities.

While selecting the hosts of the World Cup, FIFA is supposedly focused on organisational capabilities. According to FIFA Statutes, the decision on the venue "aims to achieve the objective of securing the best possible hosting conditions in the host country" (FIFA, 2018, p. 61). This is also connected to the expectation of political engagement by the state, as formally it is the member association, not the government, that bids for the World Cup. Nevertheless, FIFA officially declares in its bidding instructions that "the broad support and acceptance by the main political parties, further stakeholders and organs in the Host Country and the Host City Authorities in each of the Host Cities, together with the strategy, vision and related objectives of the Government as reflected in its Government Vision Statements" is regarded as an important factor for success in bidding for the World Cup (FIFA. Structure...). The fact that FIFA, a sports non-governmental organization, expects declarations of support from political subjects has a diplomatic significance on its own merit. Accordingly, with the understanding of sports diplomacy as a diplomacy with sports organizations 
as its actors, it engages governments (primary diplomatic subjects) and other political actors in communications, negotiations and generally contacts with FIFA. Interestingly, these relations are asymmetrical, with governments acting as sports organizations' petitioners.

The brief review of the FIFA World Cup selection procedure reveals to some extent how the whole process works. The decision, which in many cases is very important for states and their governments, is made by a number of sports officials from different countries. Today it belongs to a wider group of delegations from virtually every country, while in the past it was in hands of few FIFA leaders. However, despite recent changes within FIFA aimed at democratisation of the procedure and securing greater transparency, the system remains blurred with strong position of the FIFA President and other leaders. This situation obviously makes FIFA President an object of states' endeavours and treating him similarly as a diplomatic representative of a state.

\section{POLITICAL LEADERS' ENGAGEMENT IN BIDDING FOR THE FIFA WORLD CUP}

The first FIFA World Cup included in the research refers to the tournament held in the United States in 1994. Selection of the host was a surprise since the country is not regarded as a "football nation", but FIFA is believed to have wanted to support development of football in the US. What is more, the country already had non-sports infrastructure and the available stadiums were easy to adjust for the needs of football matches (Nadel, 2014). Although in the US sport does not belong to the explicit sphere of interest of the federal government, American President Ronald Reagan backed American bid with videotaped two-minute speech which was broadcasted to the EC (Lewis, 2015). The direct support or lobbying for the American bid by the members of American federal administration was rather limited then, however still visible.

The state leaders were much more engaged in bidding for the FIFA World Cup held in France in 1998. Interestingly, the event had an explicit nation branding and public diplomacy objective for France. The tournament was intended to showcase French industry and high technology including construction, high speed TGV trains, telecommunications, etc., and to stimulate investments and tourism, although internal political goals were also visible, such as associating national and local politicians with a major world event (Dauncey \& Hare, 1999). 
As to the national leaders' engagement in backing French bid, earlier the Prime Minister and at the time of FIFA's decision the mayor of Paris Jacques Chirac was very active, which included direct negotiations with FIFA President João Havelange. French President François Mitterrand was also engaged and awarded Havelange with highest French order Legion of Honour. It was interpreted as an attempt to counter Noble Peace Prize nomination by the Swiss - an incentive by another bidder for the World Cup (Sugden \& Tomlinson, 2017). A much more proactive stance of French political leaders in backing the French World Cup bid could therefore be observed comparing to the previous World Cup. Interestingly, the 1998 tournament had much more explicit public diplomacy and nation-branding goals than the one in 1994. It should also be mentioned that in European states, governmental engagement in elite sport is more direct than in the US, which could also be the reason.

The situation before the host of the 2002 World Cup was selected was extraordinary. The bidding process could be described by a fierce competition between South Korean and Japanese bids. This ended up with a solution to co-host the event by both countries after Japanese eventually agreed (Longman, 1996). But before it happened both individual bidding committees enjoyed a strong backing from the states' authorities. In case of Korea, Deputy Prime Minister Lee HongKoo became the chairman of the bidding committee. The committee also engaged people from the Korean Foreign Ministry and placed secretaries in embassies of each country of the members of FIFA EC. Apart from that, Korean President Kim Young-Sam held meetings with members of FIFA EC and went jogging every day with a "2002 World Cup" t-shirt. The Japanese bidding committee was composed of sports officials rather than politicians, but in response to South Korean former Prime Minister Miyazawa Kiichi was appointed as honorary chairman (Butler, 2002). Despite a different character of both bids, as we now know they ended as a joined bid and can definitely be described as one that was backed by national political leaders. Worth to mention that like the France '98 World Cup, it also had public diplomacy and nation-branding goals. Most of all, it is associated with fostering Japanese-Korean friendship. As Korean President stated in the telegram after receiving the right to co-host the tournament, "I believe that the co-hosting of the 2002 World Cup will serve as an occasion to further solidify the friendly relations of Korea and Japan" (Varcoe, 2002). However, this goal appeared after the idea of co-hosting had been realized, whereas governmental engagement was visible even before that. It is however believed that from the Korean perspective the tournament, apart from fostering proximity with Japan, 
resulted in boosting the country's image abroad and brought a number of direct and non-direct economic benefits including expansion of tourist infrastructure and improvement of Korean brands and products (Merkel, 2008). Again, state engagement in the World Cup bidding process was accompanied by public diplomacy and nation-branding goals of bidding for the event.

Another European World Cup finals were held in 2006 in Germany. The tournament had explicit public diplomacy and nation-branding objectives. They included impacting positively on the country's poor image abroad and increasing tourism and inward investment, although this appeared to be the secondary goal to increasing Germany's international prestige (Grix, 2012). Concerning the state leaders' engagement in the bidding process, a strong support by German Chancellor Gerhard Schröder could be observed. The head of German government visited FIFA headquarters a day before the selection of the World Cup host (FIFA, 2000), although this was just one of his activities. Earlier he met with FIFA President Sepp Blatter in Berlin in October 1999. During the meeting Schröeder assured of "the unrestricted support of the bid by the entire German government" (FIFA, 1999). Schröeder had also made numerous trips to promote the bid (Kirschbaum, 2016). He was also a member of German delegation to FIFA EC before its final decision (Millward, 2000). The connection between the World Cup host branding and public diplomacy goals and the engagement of state officials could also be observed then.

While discussing the bidding process for the 2006 World Cup, it is worth to mention that other bidders were also excessively supported by political leaders. England's bid was supported by Prime Minister Tony Blair who met with outgoing FIFA President Havelange in London (Sugden \& Tomlinson, 2017), while the events shortly before FIFA decision were reported to be even more interesting. South African bid was backed by former President Nelson Mandela, who supposedly called the King of Thailand and the Emir of Qatar for their support. The King of Belgium had called Belgium FIFA EC member Michel D'Hooghe, after which he sustained his support for German bid (Bose, 2000). The whole process of looking for votes by respective bidders revealed a close bond between sport and politics despite their declared distinctiveness. It has also shown how bidding for sports events is associated with international negotiations.

2010 marked the first ever sports mega-event held in Africa, although this was clear even before the final decision by FIFA which in response to controversies with selecting the 2006 host assured that an African nation would host the event in 2010 (Matheson \& Baade, 2004). South Africa won over Morocco 14-10 in the 
first round of vote (FIFA. Factsheet...). During the bidding process South African state support was very strong. Its delegation to Zurich included former President Nelson Mandela and current President Thabo Mbeki (Jackson, 2009). Like four years earlier, hosting the tournament had diplomatic and branding purposes for the state. The main theme was connected to African unity. Mbeki already in his speech after South Africa's election said that it was "an African bid and the World Cup would be an African World Cup hosted in partnership with all of Africa's nations" (Ndlovu, 2010, p. 147). The event is also believed to have been used to highlight economic successes, diplomatic importance and soft power (Schausteck de Almeida, Bolsmann, Marchi Júnior, \& de Souza, 2015).

Brazil hosted two of the most important sports mega-events within two years. First, in 2014, the FIFA World Cup was held in this South American country, while two years later Rio de Janeiro organised the Olympic Games. The FIFA World Cup had explicit branding goals from the moment Brazilian bid was submitted. The tournament was supposed to be an opportunity to show the world the Brazilian growing and stable economy, as Brazilian President Luiz Inácio Lula da Silva stated when the bid was confirmed (Schausteck de Almeida, Marchi Júnior, \& Pike, 2014). Similarly to the Rio Olympics in 2016, the World Cup was regarded by the government as a cheap means of improving the state's image, credibility, economic competitiveness (Murray, 2018). Brazilian World Cup was therefore a strictly public diplomacy and nation-branding endeavour by state authorities.

When bidding for the FIFA 2014 World Cup is considered, Brazil was the only candidate to hosting the event. This was the result of the rotation principle introduced by FIFA in 2003 and the tournament was supposed to be held in South America (FIFA. Factsheet...). In such situation, less intense political engagement in supporting the bid would be expected. On the contrary, the bidding campaign was fully endorsed by the national government (Horne \& Silvestre, 2016). When FIFA inspection committee visited Brazil, it reported having met with the President of the Republic, various government ministers, state governors and the mayors of the prospective host cities. According to the commission their commitment spoke in favour of Brazil's hosting the World Cup (FIFA, 2017). The personal support of President Lula da Silva was also very clear (FIFA, 2008). On the occasion of awarding the tournament to Brazil he declared that football was "more than a sport for Brazilians, it is a national passion", although his support started much earlier when in 2004 he attended a friendly match between Brazil and Haiti as part of the United Nations mission led by Brazilian troops (Horne 
\& Silvestre, 2016). The governmental and presidential support for the Brazilian bid was very strong.

Situation with Russia, the next World Cup host, was fairly similar as the two major sports events were held there in a very short period. First Sochi hosted the Olympic Winter Games in 2014, while four years later Russia organized the FIFA World Cup. Russian Prime Minister at the time of bidding, Vladimir Putin, was very strongly engaged in applying for both of these events. Concerning the World Cup, Russian proposal was prepared by Minister of Sport Vitaly Mutko by the order of Putin (Sputnik News, 2009), whose personal activities included meeting with FIFA President Sepp Blatter in Moscow in 2009 (FIFA, 2009). He was not present in Zurich when the final decision was made, but once Russia was selected he flew to Switzerland immediately to join in the celebrations. In one of the interviews at the time he said: "We can organise a great World Cup and we want people to discover Russia" (FIFA, 2011, p. 72). The whole bid can therefore be described as very strongly supported by the government, or even state led, with a very strong support of Vladimir Putin. This is another similarity to the Brazilian case.

It may be assumed that like in Brazil, both sports mega-events held lately in Russia were supposed to have significance in terms of public diplomacy and nation-branding. Such was probably the objectives of bidding for both of them. However, according to Müller (2017), in the end such goals were only subsidiary concerning the World Cup, due to growing international apprehensiveness of Russia's aggressive foreign policy. However, before the Crimea crisis both events were believed to have branding and diplomatic objectives connected to the goal of enhancing Russia's negative international image (Grix, 2015). Therefore, even though in the end Russia's 2018 World Cup was not explicitly a public diplomacy and nation-branding event, such were the goals at the bidding stage and this could explain such strong engagement by state authorities including Vladimir Putin.

During the same meeting FIFA EC selected Qatar as the host of 2022 World Cup. The decision was controversial, particularly because of the tiny size of Qatar and the hot climate. The bidding process has also brought allegations of corruption and "buying" votes. From the perspective of Qatar, the application was strongly supported by national leaders who personally backed it. When the decision was announced, Emir of the State of Qatar Sheikh Hamad bin Khalifa Al-Thani and his wife personally took the World Cup trophy from FIFA President Sepp Blatter (Swart, Bob, \& Turco, 2013). State engagement in the bidding 
was much more intensive though, as Emir's son Sheikh Mohammed bin Hamad bin Khalifa Al-Thani became the chairman of the bid committee (Kummels, 2013). As a member of the Royal House he should also be regarded as a state representative.

Although the World Cup in Qatar will be held in a couple of years, it can already be stated that public diplomacy and nation-branding belonged to the prime motivations of bidding and future hosting. After Qatar was awarded the tournament Sheikh Mohammed bin Hamad bin Khalifa Al-Thani declared that one of its most important aspects is that it would "enable us to sweep away outdated prejudices" (FIFA, 2011, p. 72). Other public diplomacy and nationbranding goals include showcasing the country and the region as a peaceful environment rather than a place of political conflicts, which is connected to an attempt to boost the level of incoming tourism (Brannagan \& Giulianotti, 2015; Henderson, 2017).

The last of the bidding processes included in the research relates to the World Cup in 2026. It is the first World Cup to be awarded by FIFA according to the new regulations, with the whole FIFA Congress to decide upon the host. The decision was extraordinary as well, since for the first time the tournament was awarded to 3 states: United States, Canada, and Mexico, although majority of matches will be played in the US which can be assumed as the leader of the bid.

American elite sport has always been separated from the federal government. This could also be observed in the earlier American bid for the 1994 World Cup, in which federal engagement was rather minor, although there have also been cases when American presidents backed American bids for sports mega-events in a more direct way, for example Barack Obama lobbied the IOC Members to vote for Chicago as the host of 2016 Summer Olympics (Markovits \& Rensmann, 2010; Cooper, 2013). When it comes to the 2026 World Cup, Donald Trump's engagement was rather untypical, since he shared veiled threats towards countries who might vote against the bid through Tweeter (Critchley, 2018). Apart from that, Trump has sent letters to FIFA President Gianni Infantino to support the bid. After the awarding Trump tweeted that he "worked hard" on the successful bid (Schad, 2018). The application was also supported by Mexican and Canadian political leaders. President of Mexico Enrique Peña Nieto and Canada's Prime Minister Justin Trudeau declared via Tweeter their support for the North American bid (Kasraoui, 2018). The application therefore did have some support from the political leaders, but on the other hand, tweeting or signing letters 
cannot be assessed as a strong and formal engagement, and consequently, as an indication of treating FIFA as a diplomatic actor.

In multi-national bids, public diplomacy and nation-branding objectives are more difficult to observe. Still, after United States, Canada and Mexico were selected as the World Cup hosts, the comments included statements that it could restore harmony between these nations, undermined as a result of Donald Trump's policy (Bilefsky, 2018), although of course such goals should not be regarded as lying behind the idea of the joint bid. Other public diplomacy and nation-branding issues have also been raised, for example, that the tournament was an opportunity to "put Canada on the world stage" was mentioned by Canadian politicians (Katsarov, 2018). Head of Mexican football federation has also mentioned that the World Cup will be used as a "platform to unite the world around football" (Graham, 2018). Some public diplomacy and nation-branding goals attached to the future North American World Cup can be observed then, but they appear to be less evident than in some of the World Cups analysed above.

\section{CONCLUSIONS}

The analysis of state leaders supporting the bids from their countries to host FIFA World Cups from the last 30 years has confirmed their engagement. Virtually every of the successful bids was at least to some extent supported by figures such as presidents, prime ministers or other prominent political leaders. Of course, the level of this engagement was different in various cases. It has been observed that there was a connection between state leaders' personal engagement and public diplomacy and nation-branding goals of organising particular tournament. The World Cups with explicit objectives of boosting state's international image and prestige were more likely to be supported by political leaders. This tendency may be derived from national interests connected to such initiatives. Mega-events such as the FIFA World Cup obviously have great impact on nations hosting them. However, such events formally are not organised by states but by national sports bodies, even though governmental support is one of FIFA's expectations from the bidder.

The level of state leaders' engagement in bidding for the FIFA World Cup, and its character, speak in favour of the hypothesis that through selecting the World Cup host FIFA obtains diplomatic subjectivity. State leaders personally 
lobby for their national bids to host this tournament because their states have interest in hosting them. Internationally such interests are most commonly about boosting national image. FIFA in this context becomes states' public diplomacy and nation-branding external stakeholder, with the World Cup as a sort of soft power asset that belongs to FIFA but is desired by states.

The form of contacts between state leaders and FIFA officials is sometimes similar to diplomatic contacts. As stated, state leaders often personally met with FIFA Presidents, invited them to their offices or houses. Their activities also included persuading FIFA members to vote for particular location and presenting bids to FIFA Executive Committee. All this shows that even though states are the most important subjects of diplomacy, in the context of bidding for the FIFA World Cup their leaders approach sports officials to get their support. At the same time, the World Cup bidding process, even after the reform within FIFA, puts its President as an important subject of the final decision. As a result, he is often treated similarly as a representative of a state. All these considerations and observations indicate that in the context of selecting the World Cup host, FIFA obtains diplomatic subjectivity.

\section{ReFERENCES:}

Adler-Nissen, R. (2016). Diplomatic Agency. In: C.M. Constantinou, P. Kerr, \& P. Sharp (eds.). The SAGE Handbook of Diplomacy (pp. 92-103). London: SAGE.

Beacom A. (2012). International Diplomacy and the Olympic Movement: The New Mediators. Basingstoke: Palgrave Macmillan.

Becker, R.J. (2013). World Cup 2026 Now Accepting Bribes: A Fundamental Transformation of FIFA's World Cup Bid Process. International Sports Law Journal, 13(1-2), 132-147. Retrieved from: file://C:/Users/UX07/AppData/Local/Temp/ SSRN-id2223798.pdf.

Bilefsky, D. (2018, June 13). Can the World Cup Restore Harmony Between Canada and the U.S.? The New York Times. Retrieved from: https://www.nytimes. com/2018/06/13/world/canada/world-cup-trudeau-trump.html.

Bose, M. (2000, July 7). How the World Cup Was Won - and Lost. The Telegraph. Retrieved from: https://www.telegraph.co.uk/sport/football/international/4757036/ How-the-World-Cup-was-won-and-lost.html.

Brannagan, P.M., \& Giulianotti, R. (2015). Soft Power and Soft Disempowerment: Qatar, Global Sport and Football's 2022 World Cup Finals. Leisure Studies, 34(6), 703-719. DOI: $10.1080 / 02614367.2014 .964291$. 
Butler, O. (2002). Getting the Games: Japan, South Korea and the Co-hosted World Cup. In: J. Horne, \& W. Manzenreiter (eds.). Japan, Korea and the 2002 World Cup (pp. 43-55). London-New York: Routledge.

Cooper, A.F. (2013). The Changing Nature of Diplomacy. In: A.F. Cooper, J. Heine, \& R. Thakur (eds.). The Oxford Handbook of Modern Diplomacy (pp. 35-53). Oxford: Oxford University Press.

Critchley, M. (2018, June 13). World Cup 2026 Awarded to USA, Mexico and Canada Joint-bid at Fifa Congress on Eve of 2018 Tournament in Russia. The Independent. Retrieved from: https://www.independent.co.uk/sport/football/world-cup/worldcup-2026-hosts-usa-morocco-announcement-fifa-congress-2018-russia-a8396621. html.

Dauncey, H., \& Hare, G. (1999). Introduction: France and France 98. In: H. Dauncey, \& G. Hare (eds.). France and the 1998 World Cup: The National Impact of a World Sporting Event (pp. 1-14), London: Frank Cass.

Eisenberg, C. (2005). From Political Ignorance to Global Responsibility: The Role of the World Soccer Association (FIFA) in International Sport during the Twentieth Century. Journal of Sport History, 32(3), 379-393.

FIFA. Factsheet, FIFA World Cup ${ }^{\mathrm{TM}}$ Host Announcement Decision. Retrieved from: https://resources.fifa.com/mm/document/fifafacts/mencompwc/51/97/81/fs201_13a_fwc-bidding.pdf.

FIFA. Structure, Content, Presentation, Format and Delivery of Bid Book. Retrieved from: https://resources.fifa.com/mm/document/affederation/administration/02/91/61/10/structure.content.and.format.of.bid_neutral.pdf.

FIFA (1999, October 21). Chancellor Gerhard Schröder Welcomes FIFA President Joseph Blatter. Retrieved from: https://www.fifa.com/worldcup/news/chancellor-gerhardschroder-welcomes-fifa-president-joseph-blatter-35212.

FIFA (2000, August). FIFA Magazine.

FIFA (2008, January). FIFA Magazine.

FIFA (2009, December). FIFA World.

FIFA (2011). 61 ${ }^{\text {st }}$ FIFA Congress, Activity Report 2010. FIFA Museum Archives, Zurich. FIFA (2017, October 30). BRAZIL BID: Inspection Report for the 2014 FIFA World Cup. Retrieved from: https://www.fifa.com/mm/document/affederation/mission/62/24/78/inspectionreport_e_24841.pdf.

FIFA (2018). FIFA Statutes, August 2018 edition.

Graham, B.A. (2018, June 13). North America to Host 2026 World Cup after Winning Vote over Morocco - as It Happened. The Guardian. Retrieved from: https://www. theguardian.com/football/live/2018/jun/13/world-cup-2026-vote-fifa-nationschoose-between-north-america-and-morocco-live.

Grix, J. (2012). 'Image' Leveraging and Sports Mega-Events: Germany and the 2006 FIFA World Cup. Journal of Sport \& Tourism, 17(4), 289-312. DOI: 10.1080/14775085.2012.760934.

Grix, J. (2015). Sport Politics: An Introduction. New York: Red Globe Press. 
Henderson, J.C. (2017). Sports Events, Tourism, Development and Regeneration: A Perspective from Gulf States of Abu Dhabi, Dubai and Qatar. In: N. Wise, \& J. Harris (eds.). Sport, Events, Tourism and Regeneration (pp. 9-23). Abingdon: Routledge.

Homburg, H. (2006). FIFA and the "Chinese Question", 1954-1980: an Exercise of Statutes. Historical Social Research, 31(1), 69-87. DOI: 10.12759/hsr.31.2006.1.69-72.

Horne, J., \& Silvestre, G. (2016). Brazil, Politics, the Olympics and the FIFA World Cup. In: A. Bairner, J. Kelly, \& J. Woo Lee (eds.). Routledge Handbook of Sport and Politics (pp. 483-495). London: Routledge.

Jackson, J. (2009, December 6). The World Cup Party Mandela Began in Zurich Arrives in South Africa. The Guardian. Retrieved from: https://www.theguardian.com/ football/2009/dec/06/south-africa-world-cup-hosts.

Jackson, S.J., \& Dawson, M.C. (2017). The IOC-State-Corporate Nexus: Corporate Diplomacy and the Olympic coup d'état. South African Journal for Research in Sport, Physical Education and Recreation, 39 (1:2), 101-111.

Kasraoui, S. (2018, April 28). Mexican, Canadian Officials Respond to Trump's Threatening Tweets on 2026 World Cup. Marocco World News. Retrieved from: https://www. moroccoworldnews.com/2018/04/245359/mexican-canadian-officials-respond-totrumps-threatening-tweets-on-2026-world-cup/.

Katsarov, Ch. (2018, June 13). Canadian Politicians Celebrate Chance to Co-host 2026 FIFA World Cup. Huffington Post. Retrieved from: https://www.huffingtonpost. ca/2018/06/13/canadian-politicians-co-host-2026-fifa-world-cup-soccer_a_2345 8415/?guccounter=1\&guce_referrer_us=aHR0cHM6Ly93d3cuZ29vZ2xlLmNvbS 8\&guce_referrer_cs=sZZTh7Q44qN_8JYhW1Dq8w.

Kirschbaum, E. (2016). Soccer Without Borders: Jürgen Klinsmann, Coaching the U.S. Men's National Soccer Team and the Quest for the World Cup. New York: Picador. Kummels, I. (2013). Anthropological Perspectives on Sport and Culture: Against Sports as the Essence of Western Modernity. In: K. Bromber, B. Krawietz, \& J. Maguire (eds.). Sport across Asia: Politics, Cultures, and Identities (pp. 11-31). New York: Routledge.

Lewis M. (2015, July 4). How USA Was Chosen to Host World Cup 94: the Inside Story of a Historic Day. The Guardian. Retrieved from: https://www.theguardian.com/ football/2015/jul/04/usa-world-cup-94-inside-story.

Longman, J. (1996, June 1). SOCCER; South Korea and Japan Will Share World Cup. The New York Times. Retrieved from: https://www.nytimes.com/1996/06/01/sports/ soccer-south-korea-and-japan-will-share-world-cup.html.

Markovits, A.S., \& Rensmann, L. (2010). Gaming the World: How Sports Are Reshaping Global Politics and Culture. Princeton: Princeton University Press.

Matheson, V.A., \& Baade, R.A. (2004). Mega-Sporting Events in Developing Nations: Playing the Way to Prosperity. The South African Journal of Economics, 72(5), 1085-1096.

Merkel, U. (2008). The Politics of Sport Diplomacy and Reunification in Divided Korea: One Nation, Two Countries and Three Flags. International Review for the Sociology of Sport, 43(3), 289-311. DOI: 10.1177/1012690208098254. 
Merkel, U. (2016). Sport as a Foreign Policy and Diplomatic Tool. In: A. Bairner, J. Kelly, \& J. Woo Lee (eds.). Routledge Handbook of Sport and Politics (pp. 28-38). London: Routledge.

Millward, D. (2000, July 7). Germany Beats England to Hold 2006 World Cup. The Telegraph. Retrieved from: https://www.telegraph.co.uk/news/worldnews/europe/ germany/1347296/Germany-beats-England-to-hold-2006-World-Cup.html.

Müller, M. (2017). How Mega-Events Capture Their Hosts: Event Seizure and the World Cup 2018 in Russia. Urban Geography, 38(8), 1113-1132. DOI: 10.1080/02723638.2015.1109951.

Murray, S. (2018). Sports Diplomacy: Origins, Theory and Practice. London: Routledge. Nadel, J. H. (2014). Cup of Welcome? Media, Marketing, Latinos, and the 1994 World Cup. In: S. Rinke, \& K. Schiller (eds.). The FIFA World Cup 1930-2010: Politics, Commerce, Spectacle and Identities (pp. 298-317). Göttingen: Wallstein.

Ndlovu, S.M. (2010). Sports as Cultural Diplomacy: the 2010 FIFA World Cup in South Africa's Foreign Policy. Soccer \& Society, 11(1-2), 144-153. DOI: 10.1080/14660970903331466.

Palmer, C. (2013). Global Sports Policy. Los Angeles: Sage.

Postlethwaite, V., \& Grix, J. (2016). Beyond the Acronyms: Sport Diplomacy and the Classification of the International Olympic Committee. Diplomacy \& Statecraft, 27(2), 295-313. DOI: 10.1080/09592296.2016.1169796.

Schad, T. (2018, June 15). Donald Trump Touts His Efforts in Successful World Cup Bid, Thanks Robert Kraft for Advice. USA Today. Retrieved from: https://eu.usatoday. com/story/sports/soccer/worldcup/2018/06/15/donald-trump-touts-world-cup2026-bid-thanks-robert-kraft/704433002/ [access date: 07.01.2019].

Schausteck de Almeida, B., Bolsmann, C., Marchi Júnior, W., \& de Souza, J. (2015). Rationales, Rhetoric and Realities: FIFA's World Cup in South Africa 2010 and Brazil 2014. International Review for the Sociology of Sport, 50 (3), 265-282. DOI: 10.1177/1012690213481970.

Schausteck de Almeida, B., Marchi Júnior, W., \& Pike, E. (2014). The 2016 Olympic and Paralympic Games and Brazil's Soft Power. Contemporary Social Science, 9(2), 271-283. DOI: 10.1080/21582041.2013.838291.

Sputnik News (2009, May 5). Putin Orders Sports Minister to Prepare Bid for 2018 World Cup. Retrieved from: https://sputniknews.com/sport/20090505121448011/.

Sugden, J., \& Tomlinson, A. (2017). Football, Corruption and Lies: Revisiting 'Badfellas', the Book FIFA Tried to Ban. London: Routledge.

Surmacz B. (2015). Ewolucja współczesnej dyplomacji. Aktorzy, struktury, funkcje. Lublin: Wydawnictwo UMCS.

Swart, K., Bob, U., \& Turco, D.M. (2013). Bidding for Major International Sporting Events. In: M. Ben Sulayem, S. O'Connor, \& D. Hassan (eds.). Sport Management in the Middle East: A Case Study Analysis (pp. 20-39). London: Routledge.

Varcoe, F. (2002, May 20). Coming to Terms with Cohosting. The Japan Times. Retrieved from: https://www.japantimes.co.jp/sports/2002/05/20/soccer/international-soccer/ coming-to-terms-with-cohosting/\#.XC3ZC1xKjIU. 